\title{
The Analysis of Fraudulent Financial Reporting Determinant through Fraud Pentagon Approach
}

\author{
Siska Apriliana ${ }^{\square}$, Linda Agustina \\ Department of Accounting, Faculty of Economics, Universitas Negeri Semarang \\ Gedung L2 Lantai 2 Sekaran Gunungpati Semarang 50229, Indonesia \\ DOI: http://dx.doi.org/10.15294/jda.v9i2.4036
}

Received: 24 April 2017. Revised: 13 June 2017. Accepted: 6 August 2017. Published: 31 September 2017

\begin{abstract}
The purpose of this study was to analyze the prediction of fraudulent financial reporting with the perspective of pentagon fraud. Pentagon fraud theory is the development of the theories of fraud triangle and fraud diamond. The Pentagon fraud theory adds an element of arrogance in addition to the other four existing elements namely pressure, opportunity, rationalization, and competence or capacity. The population in this study were 157 manufacturing companies listed on the Indonesia Stock Exchange (IDX) period 2013-2015. The samples of 46 companies were obtained by using purposive sampling technique, so the analysis unit was 138. Data was analyzed by using descriptive statistical analysis and logistic regression analysis. The test result showed that financial stability, the quality of external auditor, and the number of CEO's photos in the annual reports of the companies had a positive effect on the prediction of fraudulent financial reporting, while financial targets, liquidity, institutional ownership, monitoring effectiveness, replacement of external auditors, and changes of corporate directors had no significant effect on the prediction of fraudulent financial reporting. The conclusion of this study indicates that unstable financial condition, the quality of corporate audit and the level of CEO's arrogance can influence the occurrence of fraudulent financial reporting.
\end{abstract}

Keywords: Pentagon Fraud; Fraudulent Financial Reporting; CEO’s Arrogance

How to cite (APA 6th Style)

Apriliana, S. \& Agustina, L. (2017). The Analysis of Fraudulent Financial Reporting Determinant through Fraud Pentagon Approach. Jurnal Dinamika Akuntansi, 9(2), 154-165.

\section{INTRODUCTION}

Financial statements are a means of communication used by a company externally and internally to provide information about the corporate activities over a certain period of time. The function of financial statements for internal parties, in this case company's management is as the basis for decision-making. Meanwhile, the function of financial statements for external parties is to inform investors and creditors about the financial performance and condition of the company during a certain period. The financial statements aim to provide information concerning the financial position of an company that is beneficial to a large number of users in economic decision-making (Harahap, 2013). The importance of presenting financial statements for the survival of the company to make managers motivated to improve the performance of the company so that the existence of the company is maintained. However, there are several cases of

Siska Apriliana $(\square)$

E-mail: aprilianasiska@gmail.com 
fraud committed by the management to display a satisfactory financial statement.

Fraud committed by companies commonly referred to as fraud, while the practice of fraudulent financial reporting known as fraudulent financial reporting. Auditing and assurance services define fraudulent financial reporting as deliberate in misstatements, omissions from amounts or disclosures with an aim to deceive users of financial statements. Fraudulent financial reporting is an act done by the board of directors of a company or government agency in order to cover the financial condition of the company. This is done by engineering the financial activity even to display the financial statements with conditions to experience profits (Prajanto \& Pratiwi, 2017).

The case of fraudulent financial reporting of go public companies becomes one of the bad factors of the economy of a country, in Indonesia some companies are known to commit fraud practices of financial statements, among others, PT Kimia Farma Tbk case, PT Kereta Api Indonesia Tbk, PT Waskita Karya Tbk. Cases of financial statements manipulation abroad have also been recorded done by Xeroc (2000), Enron (2001) and Worldcom (2002) which caused the United States public to doubt the integrity and credibility of business actors. The recent case of fraudulent financial reporting is committed by PT Timah (Persero) which is accused of manipulating its financial statements in the first semester - 2015 stating that there is a temporary positive performance increase, in fact there is a loss of Rp 59 billion (Okezone Finance, 2016). Another case of fraudulent financial reporting is committed by Toshiba Corporation, which in 2015 proved to have made a profit bubble equivalent to 1.22 billion USD in five years.

The cases that occurred indicate that fraudulent financial reporting harms various parties. The presentation of data that is not in accordance with the actual conditions in the financial statements cause the displayed information is not relevant to be made decision-making materials. The financial statements that have been manipulated make big losses for investors in which their investment will not get a return on the capital invested. Association of Certified Fraud Examiners (ACFE, 2016) states that fraudulent financial reporting at the company were occupied by the owner or executives as the perpetrators, followed by the managers and employees as the perpetrators of fraud.

Previous researches on fraud is still dominated by the fraud triangle model that are Kusumawardhani (2013), Ardiyani \& Utaminingsih (2015), Abayomi (2016), Iqbal \& Murtanto (2016), while Sihombing \& Rahardjo (2014) examine Fraud diamond. There is still little research that analyzes fraud uses Crowe's fraud pentagon theory (Marks, 2012) with proxy of fraudulent financial reporting uses beneish $\mathrm{m}$-score.

This study aims to analyze the determinants of fraudulent financial reporting through the pentagon fraud approach which consisted of elements pressure with variables of financial targets, financial stability, liquidity, institutional ownership; element of opportunity with variable of effective monitoring and quality of external auditor, element of rationalization with variable of changes in auditor; competence with variable of change of company directors; as well as element of arrogance with variable of frequent number of CEO's picture.

The theory used in this research is agency theory and crowe's fraud pentagon theory. Agency theory is a distinction of interest between managers and shareholders that impacts on the occurrence of conflict of interest. Based on this theory, the shareholders want the management to display financial statements in accordance with the real conditions of the company, while the management tries to meet the request by doing various ways to get high salaries and bonuses. Crowe's pentagon fraud theory explains the elements of the cause of the fraud through five elements that is pressure, opportunity, rationalization, capability or competence, and arrogance. These five elements consist of financial and non-financial factors that are used as an indication of the cause of fraud to the corporate financial statements.

Financial targets are financial targets in the form of return on the business set by the directors or management. Agency theory can explain the pressure gotten by management to generate high profits in accordance with the wishes of the owner. The high level of profits set by 
the company make the management does various ways to make financial statements look good. Return on Assets (ROA) is a ratio that shows the result of return on the amount that has been used by the company. The actual ROA that has been achieved by the company in the previous year becomes a benchmark for the company to achieve the same target or even higher in the next year. The higher ROA that will be achieved by the company makes the probability of fraudulent financial statements higher. (Rahman, 2011) proves that ROA has a significant influence on fraudulent financial reporting.

$\mathrm{H}_{1}$ : Financial targets has a positive effect on fraudulent financial reporting

Financial stability is a stable financial condition in a company. In accordance with agency theory, management seeks to keep corporate financial condition stable in various ways. This is because of pressure in order to companies get a lot of capital from investors. Skousen, Smith, \& Wright (2009) say the company will seek to improve its prospects, one of which is by manipulating information on asset growth owned. Assets are a reflection of the corporate wealth that can show the outlook of a company (Rahmanti \& Daljono, 2013). Companies are said big or small can be seen from the total assets. Sihombing \& Rahardjo (2014), Tiffani \& Marfuah (2015), Iqbal \& Murtanto (2016), Tessa \& Harto (2016) proves that the more unstable a corporate financial condition, the more likely the company will commit fraud.

$\mathrm{H}_{2}$ : Financial stability has a positive effect on fraudulent financial reporting

The liquidity of a company describes the company's ability to settle its short-term liabilities. Agency theory explains the management gets pressure for the company to have a high level of liquidity. This prompted the management to commit fraud to meet the demand. The higher the level of corporate liquidity then the possibility of fraudulent acts of financial statements will be higher. Harahap (2013) states that liquidity can be calculated through sources of information about working capital that is contained in items of current assets and current liabilities. Perols \& Lougee (2011) as well as Kirkos, Spathis, \& Manolopoulos (2007) find that when companies have low liquidity, it will cause big possibility to engage in fraudulent financial reporting. Kreutzfeldt \& Wallace (1986) proves that companies with liquidity problems have a more significant error in their financial statements than other companies that do not experience liquidity problems.

$\mathrm{H}_{3}$ : Liquidity has a positive effect on fraudulent financial reporting

Institutional ownership is a shareholding by an institution such as insurance, bank, corporate investment, and other institutional ownership. Institutional ownership has an important meaning in monitoring management because it will encourage the enhancement of more optimal monitoring. A large number of shareholders have an important meaning in monitoring manager behaviour. Given the concentration of ownership, large shareholders such as institutional ownership will be able to monitor the management team more effectively (Puspitasari, 2014) $\mathrm{H}_{4}$ : Institutional ownership has a negative effect fraudulent financial reporting

The occurrence of fraud practices is one of the impacts of weak corporate monitoring so as to provide an opportunity for agents or managers to behave deviant by committing fraud (Sambera \& Meiranto, 2013). Agency theory explains the effectiveness of monitoring conducted by the principal against the management for the company to operate well. Effective monitoring is a condition of effectiveness of the internal control system within a firm. The practice of cheating or fraud can be minimized one of them with a good monitoring mechanism (Skousen et al., 2009). An independent board of commissioners is believed to be able to increase the effectiveness of corporate monitoring, so the more effective the monitoring done by independent board of commissioners so the possibility of fraud becomes lower Rahman(2011). Sihombing \& Rahardjo (2014) proves the negative effect of monitoring effectiveness on financial reporting fraud. It is supported by Tiffani \& Marfuah(2015) and Skousen et al.(2009) which states that the higher the effectiveness of corporate monitoring will lower the potential for management to commit fraudulent financial reporting,

$\mathrm{H}_{5}$ : Effective monitoring has a negative effect on fraudulent financial reporting

Auditor quality is seen as the ability to enhance the quality of a financial statement for 
the company. Pentagon fraud theory explains the possible opportunity done by management by selecting a Public Accounting Firm (KAP) that can be invited to work together to commit fraud. The larger KAP size which audits, the better the audit quality produced so that it will minimize the possibility of fraudulent acts of financial statement Ardiyani \& Utaminingsih (2015). The use of external auditor services by a company can be a benchmark of the financial statements quality displayed by the company. This opinion is reinforced by the statement of Deangelo (1981) who states that the audit quality of public accountants can be seen from the size of the KAP which audits. Raenaldi (2015) proves that BIG 4 KAP has a significant influence on fraud.

$\mathrm{H}_{6}$ : External Auditor Quality has a negative effect on fraudulent financial reporting

External auditor is a party considered to have an independent attitude so as to reveal fraud committed by a company. The Pentagon fraud theory explains the rationalization attitude of management by conducting change of KAP for fraud in the previous period is not revealed. The more companies change the KAP then it is indicated that the company wants to cover up the fraud that has been done. Changes in auditor are a proxy of rationalization in which changes in auditors are considered as an attempt to eliminate traces of fraud (fraud trail) found by previous auditors. This tendency causes the management to replace the independent auditor used in the previous period to cover the fraud that occurred within the company.

Saputra (2016) proves that changes in auditor positively influence fraudulent financial reporting. This is in line with the research undertaken by Ghosh, Marra, \& Moon (2010) and Shu (2000) in Lou \& Wang (2009) who find evidence that auditor's resignation is positively related to the possibility of fraud.

$\mathrm{H}_{7}$ : Changes in auditor have a positive effect on fraudulent financial reporting

Change of corporate directors is one of the company's efforts to improve performance in the previous period. The Pentagon fraud theory explains the capacity owned by the board of directors to the company, so it has more information that can be used to commit fraud. The change of corporate directors is done based on the result of General Meeting of Shareholders (GMS). Saputra (2016) said that the change of corporate directors is closely related to politics and the interests of certain parties which invite the existence of conflict of interest.

Priantara in Saputra (2016) states that a change of directors in a company can lead to a bad condition (stress period) where the condition can be an opportunity for individuals to take the opportunity by taking desired advantage, which can affect the existing fraudulent rate is increasing. Ruankaew (2016) as well as Saputra (2016) proves that the change of corporate directors affect on fraudulent financial reporting.

$\mathrm{H}_{8}$ : Change of corporate directors has a positive effect on fraudulent financial reporting

The role of a leader is the main key to a corporate success. A good leader is a leader who not only wants to be honoured and respected by his employees, but a leader who wants to work together and participate in building the company. The element of arrogance is explained by pentagon fraud theory with the number of CEO photographs emblazoned in an annual report of the company. A CEO tends to show everyone the status and position he has in the company because he does not want to lose that status and position. A high degree of arrogance and superiority can lead to fraud because the CEO feels that any internal control does not apply to him. Marks (2012) argues that the possibility of the CEO will do everything in order to maintain his position and place. Tessa \& Harto (2016) proves that the number of CEO's photos has a significant effect on fraudulent financial reporting.

$\mathrm{H}_{9}$ : Frequent number of CEO's picture has a positive effect on fraudulent

\section{Financial reporting}

The model of this study based on description above can be seen on Figure 1 


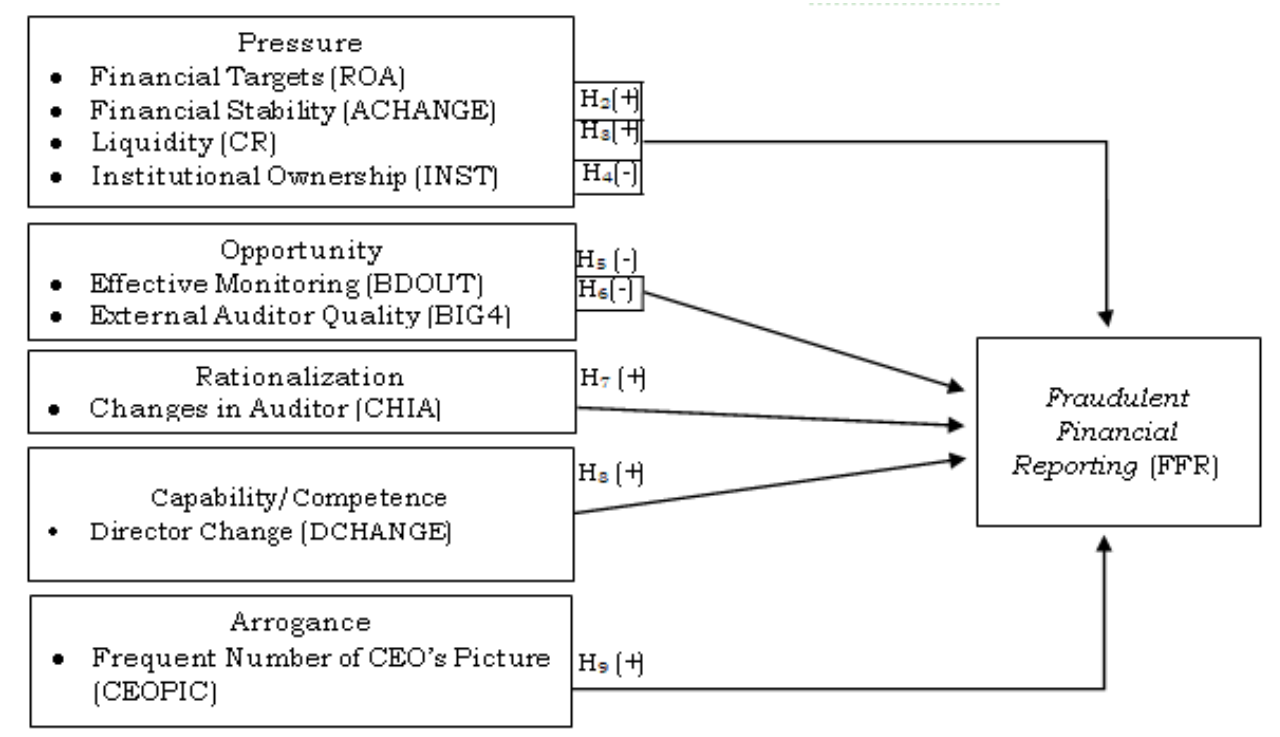

Figure 1. Research Model

\section{METHOD}

This research is a quantitative research. The population used in this study are all manufacturing companies listed in Indonesia Stock Exchange during 2013-2015 numbered 157 companies. Sampling is done by using purposive sampling technique. The criteria used to select the sample are as follows:

Table 1. Criteria of Sample

\begin{tabular}{lcc}
\hline Criteria & Not Included Criteria & Number \\
\hline $\begin{array}{l}\text { Manufacturing Companies listed on IDX 2013 - 2015 } \\
\text { Companies that present financial statements in a row dur- } \\
\text { ing the study period }\end{array}$ & $(37)$ & 157 \\
$\begin{array}{l}\text { Companies which display financial statements in nominal } \\
\text { Rupiah }\end{array}$ & $(23)$ & 97 \\
$\begin{array}{l}\text { Companies that do not suffer losses in the year of observa- } \\
\text { tion }\end{array}$ & $(48)$ & 49 \\
$\begin{array}{l}\text { Companies that do not provide complete data for variable } \\
\text { purposes }\end{array}$ & (3) & 46 \\
\hline
\end{tabular}

Source : secondary data processed, 2017

This study uses one dependent variable and nine independent variables as follows:

Table 2. Operational Definition of Variables

\begin{tabular}{llll}
\hline Variables & Operational Definition & Measurement & Scale \\
\hline Fraudulent & Misstatement or deliberate disappear- & Model of Beneish M-Score & Nom- \\
Financial & ance of amount or disclosure in financial & & inal \\
Reporting & statements (Beneish, Lee, \& Nichols, & & \\
(FFR) & 2012) & &
\end{tabular}




\begin{tabular}{|c|c|c|c|}
\hline Variables & Operational Definition & Measurement & Scale \\
\hline $\begin{array}{l}\text { Financial } \\
\text { Target } \\
\text { (ROA) }\end{array}$ & $\begin{array}{l}\text { Profit Target to be achieved by a com- } \\
\text { pany (Wilopo, 2006) }\end{array}$ & $\frac{\text { Net Profit }}{\text { Total Asset }}$ & Ratio \\
\hline $\begin{array}{l}\text { Financial } \\
\text { stability } \\
\text { (HANGE) }\end{array}$ & $\begin{array}{l}\text { Financial condition of a company (Sk- } \\
\text { ousen et al., 2009) }\end{array}$ & $\frac{\text { Total Asset } \mathrm{t}-\text { Total Asset }}{\frac{\mathrm{t}-1}{\text { Total Asset } \mathrm{t}}}$ & Ratio \\
\hline $\begin{array}{l}\text { Liquidity } \\
\text { (CR) }\end{array}$ & $\begin{array}{l}\text { The ability of companies to settle short- } \\
\text { term obligations (Harahap, 2013) }\end{array}$ & $\frac{\text { Total Current Asset }}{\text { Total Current Liability }}$ & Ratio \\
\hline $\begin{array}{l}\text { Institutional } \\
\text { ownership } \\
\text { (INST) }\end{array}$ & $\begin{array}{l}\text { Company shareholdings by other institu- } \\
\text { tions (Tessa \& Harto, 2016) }\end{array}$ & $\begin{array}{l}\text { Shares owned by other insti- } \\
\underline{\text { tutions }} \\
\text { Shares outstanding }\end{array}$ & Ratio \\
\hline $\begin{array}{l}\text { Effective } \\
\text { monitoring } \\
\text { (BDOUT) }\end{array}$ & $\begin{array}{l}\text { Effectiveness of monitoring within the } \\
\text { company (Skousen et al., 2009) }\end{array}$ & $\begin{array}{l}\text { the number of independent } \\
\text { board of commissioners } \\
\text { The total number of boards } \\
\text { of commissioners }\end{array}$ & Ratio \\
\hline $\begin{array}{l}\text { External } \\
\text { Auditor } \\
\text { Quality } \\
\text { (BIG) }\end{array}$ & $\begin{array}{l}\text { Quality of KAP used by company (BIG4 } \\
\text { or Non-BIG4) (Tessa \& Harto, 2016) }\end{array}$ & $\begin{array}{l}\text { Dummy variable, code } 1 \\
\text { for companies that use the } \\
\text { services of KAP BIG4, oth- } \\
\text { erwise coded } 0\end{array}$ & $\begin{array}{l}\text { Nom- } \\
\text { inal }\end{array}$ \\
\hline $\begin{array}{l}\text { Changes in } \\
\text { auditor } \\
\text { (CHIA) }\end{array}$ & $\begin{array}{l}\text { Change of Public Accounting Firm } \\
\text { (KAP) annually by the company (Skous- } \\
\text { en et al., 2009) }\end{array}$ & $\begin{array}{l}\text { Dummy variable, if there is } \\
\text { a change of Public Account- } \\
\text { ing Firm over the period } \\
2013-2015 \text { then it is coded } 1 \text {, } \\
\text { otherwise given code } 0\end{array}$ & $\begin{array}{l}\text { Nom- } \\
\text { inal }\end{array}$ \\
\hline $\begin{array}{l}\text { Directors } \\
\text { Change } \\
\text { (CHANGE) }\end{array}$ & $\begin{array}{l}\text { Change of directors annually by the com- } \\
\text { pany (Tessa \& Harto, 2016) }\end{array}$ & $\begin{array}{l}\text { Dummy variable, if there is } \\
\text { a change of director in the } \\
\text { company then it is coded } 1 \text {, } \\
\text { otherwise given code } 0\end{array}$ & $\begin{array}{l}\text { Nom- } \\
\text { inal }\end{array}$ \\
\hline $\begin{array}{l}\text { Frequent } \\
\text { number } \\
\text { of CEO's } \\
\text { picture } \\
\text { (CEOPIC) }\end{array}$ & $\begin{array}{l}\text { Number of CEO's photos in Annual Re- } \\
\text { port (Mohamed, Khair, \& Simon, 2015), } \\
\text { (Tessa \& Harto, 2016) }\end{array}$ & $\begin{array}{l}\text { Total photos of CEOs } \\
\text { emblazoned in an annual } \\
\text { report of the company }\end{array}$ & $\begin{array}{l}\text { Nom- } \\
\text { inal }\end{array}$ \\
\hline
\end{tabular}

Sources : Researcher Summary, 2017

The data used in this study is secondary data that is the annual financial statements of the company for the period of 2013-2015. Data collection is done by documentation technique that is by downloading the corporate annual report data contained on the corporate website or data published by the Indonesia Stock Exchange (IDX) at www.idx.co.id. Data analysis used in this research is descriptive statistical analysis and inferential statistical analysis which is logistic regression analysis. The model used in this study can be formulated as follows:

$\mathrm{Ln}=\alpha+\beta$ ROA $+\beta$ ACHANGE $+\beta$ CR $+\beta$ INST $+\beta$ BDOUT $+\beta$ CHIA +

$\beta$ DCHANGE $+\beta$ CEO $+e$

\section{RESULTS AND DISCUSSIONS}

Logistic regression was used as a model because the dependent variable in this research 
was fraudulent financial reporting was a variable that was categorized/dichotomy (companies predicted to commit fraud or not). Nagelkerke R Square value of data processing showed the result of 0.286 which meant that variability of the dependent variable explained by independent variables equal to $28,6 \%$ while the rest equal to $71,4 \%$ explained by other variable outside model of this research. After parametric statistics (logistic regression) was done, it was found problems of data normality on independent variables. The slope of the data distribution found was so extreme that it was needed to be transformed by using rank regression. Therefore, ordinary logistic regression could not be applied. This study then used non-parametric regression in the form of rank regression. The step taken was by conducting data transform of independent variable that was not a nominal variable by using rank regression. Furthermore, logistic regression was performed using data from independent variables that were not nominal variables that have been in transformed with rank regression. The results of hypothesis testing could be seen in table 3 .

Table 3. Hypothesis Test

\begin{tabular}{|c|c|c|c|c|}
\hline Hypothesis & $\beta$ & Sig. & $\alpha$ & Explanation \\
\hline $\begin{array}{l}\mathrm{H}_{1} \text { : Financial target had a positive effect on fraudu- } \\
\text { lent financial reporting }\end{array}$ & 0.013 & 0.147 & 0.05 & $\mathrm{H}_{1}$ was Rejected \\
\hline $\begin{array}{l}\mathrm{H}_{2} \text { : Financial stability had a positive effect on } \\
\text { fraudulent financial reporting }\end{array}$ & 0.016 & 0.018 & 0.05 & $\mathrm{H}_{2}$ was Accepted \\
\hline $\begin{array}{l}\mathrm{H}_{3} \text { : Liquidity had a negative effect on fraudulent fi- } \\
\text { nancial reporting }\end{array}$ & 0.010 & 0.194 & 0.05 & $\mathrm{H}_{3}$ was Rejected \\
\hline $\begin{array}{l}\mathrm{H}_{4} \text { : Institutional ownership had a negative effect on } \\
\text { fraudulent financial reporting }\end{array}$ & 0.006 & 0.360 & 0.05 & $\mathrm{H}_{4}$ was Rejected \\
\hline $\begin{array}{l}\mathrm{H}_{5} \text { : Effective monitoring had a negative effect on } \\
\text { fraudulent financial reporting }\end{array}$ & -0.003 & 0.696 & 0.05 & $\mathrm{H}_{5}$ was Rejected \\
\hline $\begin{array}{l}\mathrm{H}_{6} \text { : External auditor quality had a negative effect on } \\
\text { fraudulent financial reporting }\end{array}$ & -1.976 & 0.006 & 0.05 & $\mathrm{H}_{6}$ was Accepted \\
\hline $\begin{array}{l}\mathrm{H}_{7} \text { : Changes in auditor had a positive effect on } \\
\text { fraudulent financial reporting }\end{array}$ & -0.685 & 0.389 & 0.05 & $\mathrm{H}_{7}$ was Rejected \\
\hline $\begin{array}{l}\mathrm{H}_{8} \text { : Director Change had a positive effect on fraudu- } \\
\text { lent financial reporting }\end{array}$ & -0.101 & 0.855 & 0.05 & $\mathrm{H}_{8}$ was Rejected \\
\hline $\begin{array}{l}\mathrm{H}_{9} \text { : Frequent number of CEO's picture had a posi- } \\
\text { tive effect on fraudulent financial reporting }\end{array}$ & 0.031 & 0.000 & 0.05 & $\mathrm{H}_{9}$ was Accepted \\
\hline
\end{tabular}

Source: Secondary data processed, 2017

\section{The Effect of Financial Targets on the Fraudulent Financial Reporting}

The result of the research showed that high low profit target was not able to show the existence of fraud action to corporate financial statement. This was due to most of the research object was a large company and has experienced operational quality improvement. This was revealed in several corporate annual reports that was through a system that has been modern; more potential human resources selection by holding special training for employees and conducting human resource competency development program. The existence of stock purchase options to management and employees also participated in reducing the occurrence of fraud action, it was because they felt to be part of the company that must participate to maintain the survival of the company.

The result of this research supported research conducted by Annisya \& Asmaranti (2016) which stated that financial targets proxied with ROA had no effect on fraudulent financial reporting. The result of this study also supported research conducted by Sihombing \& Rahardjo (2014) which states that the quality improvement of the company could be caused by improving corporate operational quality such as modernization of information systems, recruitment of 
potential labor and appropriate policy of directors in solving problems.

\section{The Effect of Financial Stability on Fraudulent Financial Reporting}

Companies with low total assets tend to commit fraud in attracting investors to invest their capital in the company. A small amount of corporate assets in the past could be a motivation for the company to increase its total assets. However, in achieving this goal, companies sometimes made it as a pressure so that management manipulated financial statements to show a significant increase in assets.

This result supported research has been conducted by Sihombing \& Rahardjo (2014), Tiffani \& Marfuah (2015) which successfully proved that asset changes had a significant effect on the tendency of fraudulent financial reporting within the company. It was also in line with the research undertaken by Skousen et al.(2009) which stated that the greater the ratio of changes in total assets of a company then the probability of fraudulent acts on the financial statements of the company became higher. Managers faced the pressure to commit fraudulent financial reporting when financial stability was threatened by the state of the economy, industry, and situation of the operating entity.

\section{The Effect of Liquidity on Fraudulent Financial Reporting}

High low level of corporate liquidity could not describe the fraud action committed by the management. This was due to the company was not too focused on liquidity in attracting investors, but by increasing the value of assets owned the comparison could be seen in the corporate financial statements. The low level of corporate liquidity was an indication that the company had a greater amount of current assets than the total current liabilities owned. In this case, it meant that the company was trying to lure investors to invest capital by displaying a high amount of assets.

The result of this study was in line with research conducted by Hanifa \& Laksito (2015) and Nugraha \& Henny (2015) which stated that liquidity had no effect on fraudulent financial reporting. A low level of liquidity could not describe the fraud committed by the management on the corporate financial statements.

\section{The Effect of Institutional Ownership on Fraudulent Financial Reporting}

Low institutional ownership indicated that in the sample companies there has been a clear separation between institutional shareholders as owners in charge of controlling companies and managers as corporate managers. The existence of a clear separation caused the manager did not have enough ability to commit fraudulent financial statements. High ownership of other institutions in the company made the corporate management more careful in presenting the financial statements. The higher level of shareholding of other institutions by insiders made the fraud level which was possible committed becoming less.

The result of this study supported research conducted by Tessa \& Harto (2016) which stated that institutional ownership was not proven to have an influence on fraudulent financial reporting predictions.

\section{The Effect of Effective Monitoring on Fraudulent Financial Reporting}

The existence of an independent board of commissioners in general would provide an increasingly independent and objective monitoring to the company. More and more independent board of commissioners were expected to further improve the performance of the company in order to remain competitive. However, according to Sihombing \& Rahardjo(2014) it would be different if there were many interventions to the independent board of commissioners that resulted in the non-objectivity of a monitoring conducted by an independent board of commissioners so that the number of independent board of commissioners in a company was not a significant factor in improving the operational monitoring of the company. This might be due to the appointment 
of independent board of commissioners only to meet the regulations that at least $30 \%$ of the total board of commissioners. So it could be concluded that many of the independent board of commissioners did not affect the existence of fraudulent financial statements that occurred. The insignificant results of this study also indicated the decreasing function of independent commissioners themselves.

This study supported researches conducted by Skousen et al.(2009), Rahman (2011), Sihombing \& Rahardjo (2014), and Tessa \& Harto (2016) which also stated that the proportion of independent board of commissioners (BDOUT) had no significant influence in detecting fraudulent financial reporting.

\section{The Effect of Auditor External Quality on Fraudulent Financial Reporting}

Large Public Accounting Firms (KAPs) were considered to have higher audit quality than small KAP because they had higher experience and expertise Francis, Michas, \& Yu (2013). If the auditors in BIG4 KAP had better expertise, it could be assumed that their clients would likely apply the accounting standards correctly and would have fewer errors in the published financial statements.

Deangelo (1981) stated that the quality of audit auditors from public accountants could be seen from the size of the Public Accounting Firm (KAP) that performed the audit. BIG4 KAP was believed to be able to perform more qualified audit than non BIG 4 KAP. The large Public Accounting Firm was considered to be more independent so that allowing them to withstand the opportunistic behaviour of management. According to the research conducted by Lennox and Pittman (2010) showed that external auditors at large audit companies "BIG4" had more ability to detect fraud compared to companies which wee audited by non-BIG4 audits.

Francis et al.(2013) stated that the larger the size of the public accounting firm, the possibility of fraud would be lower because the large public accounting firm was considered to have a higher experience and expertise on the client industry. Similar results were also evidenced by Zhizhong, Juan, Yanzhi, \& Wenli (2011), where the size of the public accountant firm had a negative effect on the possibility of fraud in the audited financial statements.

This result supported research conducted by Raenaldi (2015)which stated that companies that used the services of BIG4 KAP were less likely to commit fraud in the next year. The expertise factor of KAP was considered to be one of the reasons the company has chosen BIG4 KAP in increasing the credibility of the company in the eyes of capital market players.

\section{The Effect of Changes in Auditor on Fraudulent Financial Reporting}

The replacement of the external auditor did not prove its influence on the fraudulent action of the financial statements. The company replaced the external auditor because it was not satisfied with the performance of the external auditor of the previous period. In addition, the company replaced the external auditor because it complied with government regulations in which the Government Regulation no. 20 of 2015 stated that the provision of audit services on the historical financial statements to an entity by a public accountant was limited to a maximum of five consecutive yearbooks. Companies that had a positive motivation used independent auditors who were completely independent and objective in conducting audits for the benefit of improving corporate performance in the future. But if a company started unsatisfied with the performance of auditors that could not be intervened or influenced by companies to manipulate the results of audits then fraud tendency would be higher. The result was in accordance with research conducted by Skousen et al.(2009), Sihombing \& Rahardjo (2014), and Tessa \& Harto (2016) which stated that changes in auditors had no effect on fraudulent financial reporting.

\section{The Effect of Changes in Corporate Directors on Fraudulent Financial Reporting}

The change of corporate directors could not prove the indication of the fraudulent acts on the financial statements of the company. Changes in the board of directors within the company 
described in the annual report might occur due to the transfer of authority and the result of the GMS. Changes made by the company were driven by a desire to improve the performance of the company from the previous period. The statement was supported Ruankaew (2016), which revealed that if the highest stakeholders in the company wanted improved corporate performance, it could be done by recruiting more competent directors than previous directors. Sihombing \& Rahardjo (2014), Hanifa \& Laksito (2015), and Tessa \& Harto (2016) stated that the change of corporate directors had no effect in detecting fraudulent financial reporting.

\section{The Effect of Frequent Number of CEO's Picture on Fraudulent Financial Reporting}

The level of arrogance proxied by CEO's photo frequency in the annual report could illustrate the indications of fraud. The more number of CEO photographs in a financial report could indicate the high level of CEO's arrogance within the company. A high level of arrogance could lead to the possibility of fraud because with the arrogance and superiority owned by a CEO, the CEO felt any every internal control would not apply to him because of his status and position. Marks (2012) stated the possibility that a CEO would do everything possible to maintain his position and status. The result of this study proved that the frequent number of CEO's picture affected the possibility of fraudulent financial reporting. Tessa \& Harto (2016) also proved that frequent number of CEO's picture had an effect on the prediction of fraudulent financial reporting.

\section{CONCLUSION}

The conclusion of this research is from nine hypotheses only three are accepted. Financial stability, the quality of external auditors and frequent number of CEOs are likely to influence fraudulent financial reporting. While financial targets, liquidity, institutional ownership, effective monitoring, changes in auditors, changes of corporate directors are not able to influence fraudulent financial reporting. Future research is expected to develop the Pentagon Fraud Theory with other fraudulent proxies such as F-Score.

\section{REFERENCES}

Abayomi, S. O. (2016). Personal Ethics and Fraudster Motivation: The Missing Link in Fraud Triangle and Fraud Diamond Theories. International Journal of Academic Research in Business and Social Sciences, 6(2), 159-165.

Annisya, M., \& Asmaranti, Y. (2016). Pendeteksian Kecurang Laporan Keuangan Menggunakan Fraud Diamond. Jurnal Bisnis Dan Ekonomi, 23(1), 72-89.

Ardiyani, S., \& Utaminingsih, N. S. (2015). Analisis Determinan Financial Statement melalui Pendekatan Fraud Triangle. Accounting Analysis Journal, 4(1), 1-10.

Beneish, M. D., Lee, C. M. C., \& Nichols, D. C. (2012). Fraud Detection and Expected Returns. SSRN Working Paper.

Deangelo, L. E. (1981). Auditor size and audit quality. Journal of Accounting and Economics, 3(3), 183-199.

Francis, J. R., Michas, P. N., \& Yu, M. D. (2013). Office size of Big 4 auditors and client restatements. Contemporary Accounting Research, 30(4), 1626-1661.

Ghosh, A., Marra, A., \& Moon, D. (2010). Corporate Boards, Audit Committees, and Earnings Management: Pre- and Post-SOX Evidence. Journal of Business Finance and Accounting, 37(9-10), 1145-1176.

Hanifa, S. I., \& Laksito, H. (2015). Pengaruh Fraud Indicators Terhadap Fraudulent Financial Statement: Studi Empiris Pada Perusahaan Yang Listed di Bursa Efek Indonesia (BEI) Tahun 2008-2013. Diponegoro Journal of Accounting, 4(4), 1-15.

Harahap, S. S. (2013). Analisis Kritis Atas Laporan Keuangan. Jakarta: Rajawali Pers.

Iqbal, M., \& Murtanto. (2016). Analisa Pengaruh Faktor-Faktor Fraud Triangle terhadap Kecurangan Laporan Keuangan pada Perusahaan Proferty dan Real Estate yang Terdaftar di Bursa Efek Indonesia. In Seminar Nasional Cendikiawan 2016 (p. 17.2-17.20).

Kirkos, E., Spathis, C., \& Manolopoulos, Y. (2007). Data mining techniques for the detection of fraudulent financial statements. Expert Systems with Applications, 32(4), 995-1003. 
Kreutzfeldt, R. W., \& Wallace, W. A. (1986). Error characteristics in audit populations-their profile and relationship to environmental-factors. Auditing-A Journal of Practice \& Theory, 6(1), 20-43.

Kusumawardhani, P. (2013). Deteksi Financial Statement Fraud dengan Analisis Fraud Triangle pada Perusahaan Perbankan yang Terdaftar di BEI. Jurnal Akuntansi Unesa, 1(3), 1-16.

Lou, Y., \& Wang, M. (2009). Fraud Risk Factor Of The Fraud Triangle Assessing The Likelihood Of Fraudulent Financial Reporting. Journal of Business \& Economics Research, 7(2), 61-78.

Marks, J. (2012). The Mind Behind The Fraudsters Crime : Key Behavioral and Environmental Elements Discussion Leader: Crowe Horwarth. Crowe Horwarth.

Mohamed, Y. K., Khair, A. H. A., \& Simon, J. (2015). Fraudulent financial reporting: An application of fraud models to malaysian public listed companies. The Macrotheme Review, 4(3), 126-145.

Nugraha, N. D. A., \& Henny, D. (2015). Pendeteksian laporan keuangan melalui faktor risiko, tekanan dan peluang (berdasarkan press release OJK 2008-2012). E-Journal Akuntansi Trisakti, 2(1), 29-48.

Perols, J. L., \& Lougee, B. A. (2011). The relation between earnings management and financial statement fraud. Advances in Accounting, 27(1), 39-53.

Prajanto, A., \& Pratiwi, R. D. (2017). The Impact of Corporate Cultures and Financial Ratios on The Fraudulent Financial Reporting. Jurnal Dinamika Akuntansi, 8(1), 39-52.

Puspitasari, A. S. (2014). Pengaruh Proporsi Dewan Komisaris Independen, Kepemilikan Manajerial dan Kepemilikan Institusional terhadap Pemberian Opini Audit Going Concern (Studi Empiris pada Perusahaan Manufaktur yang Terdaftar dI Bursa Efek Indonesia Tahun 2010-2012). Disertasi Universitas Atma Jaya Yogyakarta.

Raenaldi, C. (2015). Pengaruh ukuran kantor akuntan publik, pengungkapan auditor lain dalam laporan auditor, dan ukuran komite audit terhadap misstatement dalam laporan keuangan auditan: studi empiris pada perusahaan non-keuangan yang terdaftar di bursa efek Indonesia periode. Disertasi Universitas Islam Negeri Syarif Hidayatullah Jakarta.

Rahman, F. (2011). Peran Manajemen dan Tanggung Jawab Auditor dalam Mendeteksi Kecurangan Laporan Keuangan. Jurnal Akuntansi, 7(53), 1816-1822.

Rahmanti, M. M., \& Daljono, D. (2013). Pendeteksian Kecurangan Laporan Keuangan Melalui Faktor Risiko Tekanan dan Peluang (Studi Kasus pada Perusahaan yang Mendapat Sanksi dari Bapepam Periode 2002-2006). Disertasi Universitas Diponegoro.

Ruankaew, T. (2016). Beyond the Fraud Diamond. International Journal of Business Management \& Economic Research, 7(1), 474-476.

Sambera, G. F., \& Meiranto, W. (2013). Analisis Pengaruh Karakteristik Dewan Komisaris dan Karakteristik Perusahaan Terhadap Pembentukan Komite Manajemen Risiko (Studi Empiris pada Perusahaan Finansial Non Perbankan yang terdaftar di BEI Tahun 2009-2011). Diponegoro Journal of Accounting, 2(3), 1-14.

Saputra, R. A. (2016). Pengaruh Fraud Indicators terhadap Fraudulent Financial Statement (Studi Empiris pada Perusahaan yang Listed di BEI Tahun 2013-2015). FE UMY.

Sihombing, K. S., \& Rahardjo, S. N. (2014). Analisis Fraud Diamond dalam Mendeteksi Financial Statement Fraud: Studi Empiris pada Perusahaan Manufaktur yang Terdaftar di Bursa Efek Indonesia (BEI) Tahun 2010-2012. Diponegoro Journal of Accounting, 3(2), 1-12.

Skousen, C. J., Smith, K. R., \& Wright, C. J. (2009). Detecting and predicting financial statement fraud: The effectiveness of the fraud triangle and SAS No. 99. In Corporate Governance and Firm Performance (pp. 53-81). Emerald Group Publishing Limited.

Tessa, C., \& Harto, P. (2016). Fraudulent Financial Reporting: Pengujian Teori Fraud Pentagon Pada Sektor Keuangan Dan Perbankan Di Indonesia. Simposium Nasional Akuntansi, 1-21.

Tiffani \& Marfuah. (2015). Deteksi Financial Statement Fraud dengan Analisis Fraud Triangle pada Perusahaan Manufaktur yang Terdaftar di Bursa Efek Indonesia LAILA. Simposium Nasioanal Akuntansi 18 Universitas Sumatera Utara, Medan.

Wilopo. (2006). Analisis Faktor-faktor yang Berpengaruh Terhadap Kecenderungan Kecurangan Akuntansi: Studi pada Perusahaan Publik dan Badan Usaha Milik Negara di Indonesia. Jurnal Riset Dan Akuntansi Indonesia, 9(3), 346-366.

Zhizhong, H., Juan, Z., Yanzhi, S., \& Wenli, X. (2011). Does corporate governance affect restatement of financial reporting? Evidence from China. Nankai Business Review International, 2(3), 289-302. 
